\title{
しゅう動面に四角穴パターンを有する液膜シールの動特性*
}

$$
\begin{aligned}
& \text { 金子覚 }{ }^{* 1} \text {, 田浦 裕 生*1 } \\
& \text { 上田範 吉*2, 辺見耕 太*3 }
\end{aligned}
$$

\section{Dynamic Characteristics of Liquid Annular Seals with Square-Hole Pattern}

\author{
Satoru KANEKO*4, Hiroo TAURA, \\ Noriyoshi UEDA and Kota HENMI \\ ${ }^{* 4}$ Department of Mechanical Engineering, Nagaoka University of Technology, \\ 1603-1 Kamitomioka-machi, Nagaoka-shi, Niigata, 940-2188 Japan
}

\begin{abstract}
The theoretical and experimental study is carried out to investigate the dynamic characteristics of the liquid annular seals with a square-hole pattern in seal stator. The mometum equations with turbulent coefficients and the continuity equation, which are averaged across the film thickness, are numerically solved in consideration of the pressure jumps at each step between the land and the square-hole regions. This pressure discontinuity is evaluated based on the continuity of volume flow rate across each step and the generalized Bernoulli equation. The numerical results of the dynamic fluid force and the dynamic coefficients agree well with the experimental results, which prove the validity of the numerical analysis. The effects of the inlet swirl velocity on the dynamic coefficients and the whirl-frequency ratio are also described for the square-hole pattern seal as well as the annular plain seal with smooth surface and the parallel-grooved seal.
\end{abstract}

Key Words : Turbulent Flow, Pressure Distribution, Vibration of Rotating Body, Annular Seals, Square-Hole Pattern, Dynamic Fluid Force, Dynamic Coefficients, Inlet Swirl Velocity

\section{1.はじめに}

ポンプの高速高圧化，小型軽量化に伴ってバランス ピストン, ウェアリングなどの液膜シールに生じる流 体力がポンプロータの振動特性に大きな影響を及ぼし ている. ポンプの高効率化のために液膜シール部に要 求される性能は, 漏れ量を低減することやロータの振 動を抑制する動的流体力がシールすきま内に生じるこ とである. この目的のためにシールしゅう動面に様々 な凹凸パターンを有するいわゆるダンパシールが提案

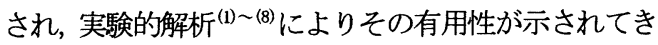
ている. しかしながら実験結果を裏付ける理論的解析 は現在のところ確立されていない. Childs ${ }^{(7)}$, Arghir $^{(9)}$ らはしゅう動面（ステータ側）に円形状の穴を有する シールの動特性を, Hirs の Bulk-flow 理論 ${ }^{(10)} に$ 基づき 解析している. その際，ロータ，ステータそれぞれの 壁面摩擦係数を, Childs ら (7) はすきま内を通過する漏 れ流量と圧力こう配の関係から実験的に求めているが,

* 原稿受付 2008 年 4 月 16 日.

*1 正員, 長岡技術科学大学工学部 (釆940-2188 長岡市上富岡 町 1603-1).

*2 長岡技術科学大学大学院工学研究科

*3 NOK (株) (凿 869-2231 阿蘇市永草 2089).

E-mail : kaneko@mech.nagaokaut.ac.jp
Arghir ら ${ }^{(9)}$ は片面に 1 個の円形状の穴を設けた平行平 板内を液体が通過する際の流孔場（乱流域）をCFD

(Computational fluid dynamics) 解析し, 得られた流速 分布及び圧力分布をもとに算出している. しかし，い ずれの解析結果も実験との定量的な一致は不十分であ り，解析の妥当性を検証するには至っていない.

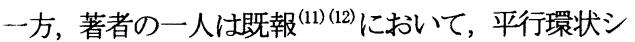
一ルの静及ひ動特性を理論的に解析し，実験結果 ${ }^{(13)}$ と の定量的な一致を得た. この解析では, 乱流状態を考 虑するため，すきまの厚さ方向に流れを平均化した Navier-Stokes 方程式に壁法則と混合距離仮説に基づき 導出された乱流係数(14)を適用し，これと連続の式とを 連立して解くことによりすきま内の圧力分布及び流速 分布を求めた.

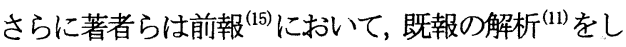
中う動面に四角穴パターンを有する環状シールの静特 性解析に適用した. その解析では，しゅう動面の凹凸 形状に伴うすきま段差部での圧力変化 (圧力損失を含 む）を，すきまの急拡大部では円管の急拡大部での実 験式を，すきま急縮小部ではステップベアリングの急 縮小部での圧力降下式(16)をそれぞれ用いて評価した. その結果, 軸方向圧力分布, 漏れ流量は実験と定性的, 定量的に比較的よく一致した. 
そこで本研究では，前報(15)の解析を動特性に展開し， その妥当性を実験との比較により検証することを目的 としている. 対象とするシールは，前報と同様に，し ゆう動面（ステータ側）に四角穴を設けたもの（四角 穴シール），さらに比較対照のための周方向に溝を設 けたもの (平行溝付シール)，しゅう動面が滑らかな もの (平行環状シール) の3 種類である. 四角穴を用 いたのは，数值解析が比較的容易なためである. 前報 と同椂に，乱流係数を用いたすきまの厚さ方向に流れ を平均化した Navier-Stokes 方程式と連続の式とを基礎 方程式とした. そしてすきま段差部での圧力変化を考 慮し，基礎方程式を連立して解くことによりすきま内 の動的な圧力分布及び流速分布を求めた. そしてロー タがシール内部を微小同心ふれまわり運動するときに 生じる動的流体力, 動特性係数 (ばね係数, 減衰係数, 付加質量係数）を算出し，実験結果と比較検討した. さらにシール入口旋回流速度が動特性係数ならびにふ れまわり周波数比（Whirl-frequency ratio）に及ぼす影 響を明らかにした。

\section{2. 本論文に用いる主要な記号}

$B_{x} \quad$ ：周方向無次元圧力こう配 $=-h^{2} /(\mu R \omega)(\partial p / \partial x)$

$B_{z} \quad$ : 軸方向無次元圧力こう配 $=-h^{2} /(\mu R \omega)(\partial p / \partial z)$

$C_{i, j}$ : 液膜の減衰係数 $[\mathrm{N} \cdot \mathrm{s} / \mathrm{m}](i, j=X, Y)$

$C_{\mathrm{m}}, C_{\mathrm{c}}: \kappa_{0}=0$ における液膜の主対角及び連成減 衰係数 $[\mathrm{N} \cdot \mathrm{s} / \mathrm{m}]$

$D \quad:$ シール内径 $=2 R \quad[\mathrm{~m}]$

$F_{\mathrm{r}}, F_{\mathrm{t}}$ : 動的流体力の半径方向, 接線方向成分 $[\mathrm{N}]$

$\overline{F_{\mathrm{r}}}, \overline{F_{\mathrm{t}}}$ : ロータの単位幅あたりに作用する動的流体 力の半径方向, 接線方向成分 $[\mathrm{N} / \mathrm{m}]$

$G_{x}, G_{z}$ : 乱流係数

$K_{i, j} \quad$ : 液膜のばね係数 $[\mathrm{N} / \mathrm{m}] \quad(i, j=X, Y)$

$K_{\mathrm{m}}, K_{\mathrm{c}} ： \kappa_{0}=0$ における液膜の主対角及び連成ば 放係数 $[\mathrm{N} / \mathrm{m}]$

$L \quad$ : シール長さ $[\mathrm{m}]$

$M_{i, j}$ ：液膜の付加質量係数 $[\mathrm{kg}](i, j=X, Y)$

$M_{\mathrm{m}}, M_{\mathrm{c}} ： \kappa_{0}=0$ における液膜の主対角及び連成付 加質量係数 $[\mathrm{kg}]$

$N$ : ロータ自転速度 [rpm]

$\mathrm{O}_{\mathrm{R}}, \mathrm{O}_{\mathrm{S}}$ ：ロータおよびシール中心

$Q$ : 軸方向流量（漏孔流量） $\left[\mathrm{m}^{3} / \mathrm{s}\right]$

$R$ : シール内半径うロータ半径 $[\mathrm{m}]$
$R_{\mathrm{h}} ：$ 周方向局所レイノルズ数 $=\rho R \omega h / \mu$

$X, Y: \mathrm{O}_{\mathrm{s}}$ を原点とした水平及び鉛直方向座標, ロータ中心 $\mathrm{O}_{\mathrm{R}}$ の座標

$c$ ： シール平均半径すきま（ランド部） [m]

$d_{\mathrm{p}}$ : 穴 (溝) 深さ $[\mathrm{m}]$

$d_{x} \quad$ : 穴の周方向長さ $[\mathrm{m}]$

$d_{z}$ : 穴 (溝) の軸方向長さ [m]

$e$ : ロータの偏心量 $[\mathrm{m}]$

$e_{\mathrm{r}} \quad:$ ロータのふれまわり半径 $[\mathrm{m}]$

$f_{X}, f_{Y}$ : 液膜反力の $X, Y$ 方向成分 $[\mathbb{N}]$

$f_{\mathfrak{w}} f_{\theta}$ : 液膜反力の偏心方向及びそれに直角方向成 分 $[\mathrm{N}]$

$h$ : 液膜厚さ $=c(1+\kappa \cos \theta)+\gamma d_{\mathrm{p}}[\mathrm{m}](\gamma=0:$ 穴 無し (ランド) 部, $\gamma=1$ : 穴部)

$l_{x} \quad:$ ランド部の周方向長さ $[\mathrm{m}]$

$l_{z} \quad:$ ランド部の軸方向長さ $[\mathrm{m}]$

$l_{z \mathrm{in}} \quad:$ シール流入部のランド部軸方向長さ $[\mathrm{m}]$

$l_{\text {zout }}$ ： シール流出部のランド部軸方向長さ $[\mathrm{m}]$

$p \quad$ : 液膜圧力 (ゲージ圧) $[\mathrm{Pa}]$

$p_{\mathrm{d}} \quad$ : 差圧 $=p_{\text {in }}-p_{\text {out }}\left(=p_{\text {in }}\right) \quad[\mathrm{Pa}]$

$p_{\text {in }}$ ： シール高圧側流入端直前 $(z=-0)$ にお ける圧力 [Pa]

$p_{\text {in }}{ }^{\prime} \quad$ : シール高圧側流入端直後 $(z=+0)$ にお ける圧力 [Pa]

$p_{\text {out }}$ ： シール低圧側流出端 $(z=L)$ における圧 力 $[\mathrm{Pa}]$

$t$ : 時間 [s]

$u, v, w$ : 流速の周 $(x)$ 方向, 液膜厚さ $(y)$ 方向, 軸 $(z)$ 方向の成分 $[\mathrm{m} / \mathrm{s}]$

$u_{\mathrm{m}}, w_{\mathrm{m}}: u, w$ のすきまの厚さ方向に平均した流 速 $[\mathrm{m} / \mathrm{s}]$

$x, y, z$ : 周方向 $(=R \theta)$, 液膜厚さ方向, 軸方向 のそれぞれの座標

$\Omega$ ：ロータのふれまわり角速度 $[\mathrm{rad} / \mathrm{s}]$

$\alpha$ : 入口旋回流速度係数

$\theta$ ： 最大寸きま位置からロータ自転方向に 測った角座標

$\theta^{\prime} \quad$ ：鉛直上方からロータ自転方向に測った 角座標

$\kappa$ : 偏心率 $\equiv / c$

$\mu$ ：作動流体（水）の粘性倸数 [Pa·s]

$\xi_{\text {in }}$ : 入口損失係数

$\rho$ : 作動流体（水）の密度 $\left[\mathrm{kg} / \mathrm{m}^{3}\right]$

$\phi_{u}: z$ 方向に単位幅あたりの $x$ 方向流量 $=h u_{\mathrm{m}}$ $\left[\mathrm{m}^{2} / \mathrm{s}\right]$

$\phi_{w}: x$ 方向に単位幅あたりの $z$ 方向流量 $=$ 


$$
\begin{aligned}
& h w_{\mathrm{m}}\left[\mathrm{m}^{2} / \mathrm{s}\right] \\
& \psi \quad: \text { 偏心角 }[\mathrm{rad}] \\
& \omega: \text { ロータの自転角速度 }[\mathrm{rad} / \mathrm{s}] \\
& \cdot \quad: \text { 時間による } 1 \text { 階微分 } \equiv \mathrm{d} / \mathrm{d} t
\end{aligned}
$$

下添字 0 : 静的平衡状態にある諸量

$\Delta:$ : 変数の微小変動量

\section{3. 解析モデルと数值解析}

図 1 には, シールすきま内で静的に偏心した状態で, 角速度 $\omega$ で自転しているロータに, 微小変位, 微小運 動速度, 微小加速度などの微小変動量を与えたときに 生じる動的な液膜反力 $f$ とその成分を示す.

3.1 基礎方程式 解析に際して前報 ${ }^{(15)}$ と同様, 以 下の仮定を設ける.

(1) 作動流体（水）は非圧縮性，等粘度である.

(2) シールすきまは他の諸寸法 (シール長さ $L$, ロー 夕直径 D）に比べて十分小さい.

(3) ランド部, 穴 (溝) 部は互いに独立したすきまの 異なる平行環状シールとみなし, 各部で平行環状 シールと同じ基礎方程式を適用する.

(4) すきま段差部近傍の流れのはく離や渦の形成, さ らに穴 (溝) 部の深さ方向（ $y$ 方向）に沿った 壁面 (側面) での流体摩擦などに伴うエネルギー 損失を, 流路の拡大損失, 縮小損失として考慮す る.

上記(1)（3)の仮定に基づきランド部および穴（溝） 部における運動方程式ならびに連続の式は次式で与え られる(12).

$$
\begin{aligned}
& \rho\left(u \frac{\partial u}{\partial x}+v \frac{\partial u}{\partial y}+w \frac{\partial u}{\partial z}\right)=-\frac{\partial p}{\partial x}+\frac{\partial \tau_{x}^{*}}{\partial y} \\
& \rho\left(u \frac{\partial w}{\partial x}+v \frac{\partial w}{\partial y}+w \frac{\partial w}{\partial z}\right)=-\frac{\partial p}{\partial z}+\frac{\partial \tau_{z}^{*}}{\partial y}
\end{aligned}
$$

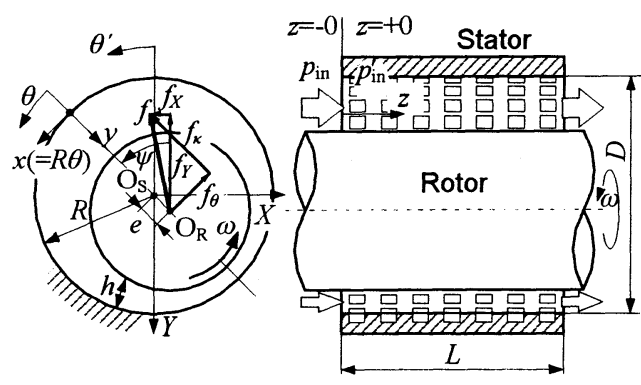

$$
\frac{\partial u}{\partial x}+\frac{\partial v}{\partial y}+\frac{\partial w}{\partial z}=0
$$

ここで $\tau_{x}^{*} ， \tau_{z}^{*}$ はそれぞれ液膜の厚さ方向に直交する $y$ 面に作用するせん断応力の $x, z$ 方向成分である. 流速 に関する境界条件は

$$
\left\{\begin{array}{l}
y=0: u=v=w=0 \\
y=h: u=R \omega, v=R \omega \frac{\partial h}{\partial x}, w=0
\end{array}\right.
$$

で与えられる. 式(4)で, $y=0$ はシールステータ表面 (ランド部表面または穴 (溝) 部の底面) に，また $y=h$ はロータ表面に位置する. 流れが十分発達した乱 流域では速度成分の形状が平均化されると仮定し， 式(4)を用いて式(1)〜 (3)をすきまの厚さ方向に積 分すると,

$$
\begin{aligned}
& \rho\left[\frac{\partial}{\partial x}\left(u_{\mathrm{m}} \phi_{u}\right)+\frac{\partial}{\partial z}\left(w_{\mathrm{m}} \phi_{u}\right)\right] \\
& =-\frac{12 \mu}{G_{x} h^{2}} \phi_{u}+\frac{6 \mu R \omega}{G_{x} h}-h \frac{\partial p}{\partial x} \\
& \rho\left[\frac{\partial}{\partial x}\left(u_{\mathrm{m}} \phi_{w}\right)+\frac{\partial}{\partial z}\left(w_{\mathrm{m}} \phi_{w}\right)\right]=-\frac{12 \mu}{G_{z} h^{2}} \phi_{w}-h \frac{\partial p}{\partial z}(6) \\
& \frac{\partial \phi_{u}}{\partial x}+\frac{\partial \phi_{w}}{\partial z}=0
\end{aligned}
$$

となる. 式(5), (6)中の $u_{\mathrm{m}}, w_{\mathrm{m}}$ はすきまの厚さ方向 に平均した $u, w$ を示す，また $G_{x}, G_{z}$ は，乱流係 数であり，圧力こう配に基づく流量と圧力こう配 の比として以下のように定義される.

$$
\begin{aligned}
& G_{x}=12\left(\frac{1}{h R \omega} \int_{0}^{h} u \mathrm{~d} y-0.5\right) / B_{x} \\
& G_{z}=12\left(\frac{1}{h R \omega} \int_{0}^{h} w \mathrm{~d} y\right) / B_{z}
\end{aligned}
$$

ここで $G_{x}, G_{z}$ の值は，壁法則と混合距離仮説に基 ゔき算出された流速分布を用いて得られる。その 際, 無次元圧力こう配 $B_{x}, B_{z}$ および周方向局所レ イノルズ数 $R_{\mathrm{h}}$ をパラメータとした ${ }^{(14)}$.

式(5) (7)を連立して解く際の, 液膜圧力 $p$, 単位 幅あたりの流量 $\phi$ ， $\phi_{w}$ に関する境界条件は前報 ${ }^{(15)}$ と同 じである. なお，シール流入端での圧力降下に伴う入口損 失係数は，前報で示した静的な軸力向圧力分布の実験結果 をもとに思=0.1とした また，すきま拡大部での損失係 数は

Fig 1 Anmular seal with square-hole pattem stator and coordinate system 


$$
\zeta_{\mathrm{e}}=\beta_{\mathrm{e}}\left(1-\frac{h_{1}}{h_{2}}\right)^{2}
$$

で表される.ここで， $h_{1}, h_{2}$ はそれぞれ段差部上 流側及び下流側のすきま厚さであり， $\beta_{e}$ は実験的に 求められる定数である. 本解析では前報 ${ }^{(15)}$ で得られた 軸方向圧力分布より, 軸方向流れに対して四角穴シー ルでは $\beta_{e}=1.4 \sim 1.6$, 平行溝付シールでは $\beta_{e}=1.2 \sim 1.4$ とした. なお周方向流れに対してはいずれの場合も $\beta_{e}$ $=1.0$ とした.

3 .2 基礎方程式の解法 すきま段差部での圧力 変化をより正確に評価するために流速と圧力を同一の 点で定義する集中格子 ${ }^{(17)}$ を用いて基礎方程式を離散 值 化 L , SIMPLE (Semi-Implicit Method for Pressure-Linked Equation) 解法により運動方程式と連 続の式を連立して解いた. 基礎方程式の離散值化及び すきま段差部での圧力変化（圧力損失を含む）を考慮 に入れた圧力補正式の導出については前報 ${ }^{(15)}$ 参照 してほしい. 離散值化に際して, シール面を周 $(x)$ 方向 に 216 等分, 軸(z)方向に 60 等分することにより差分 格子を構成した. 離散值化した運動方程式と圧力補正 式を連立して解く際の収束計算には，三重対角行列解 法(TDMA) と緩和法を組み合わせて行った. 収束判定 条件は前報 ${ }^{(15)}$ と同様である.

液膜圧力が求まれば液膜反力 $f$ 偏心方向成分 $f_{\kappa}$ と それに直角方向成分 $f_{\theta}$ は次式で与えられる.

$$
\begin{aligned}
& f_{K}=-\int_{0}^{L} \int_{0}^{2 \pi} p R \cos \theta d \theta d z \\
& f_{\theta}=\int_{0}^{L} \int_{0}^{2 \pi} p R \sin \theta d \theta d z
\end{aligned}
$$

これより液膜反力の水平方向, 鉛直方向成分は

$$
\left\{\begin{array}{l}
f_{X}=f_{\kappa} \sin \psi-f_{\theta} \cos \psi \\
f_{Y}=f_{\kappa} \cos \psi+f_{\theta} \sin \psi
\end{array}\right.
$$

となる. ここで, $f_{X}, f_{Y}$ の正の方向は, $-X,-Y$ 方向と する. また偏心角 $\psi$ 怄, 静的平衡状態の場合には,

$$
\psi_{0}=\tan ^{-1}\left(f_{\theta_{0}} / f_{\kappa_{0}}\right)
$$

で与えられる.さらにシール中心を原点とした静的平 衡状態におけるロータ中心の座標は，收を用いて

$$
X_{0}=e \sin \psi_{0}, Y_{0}=e \cos \psi_{0}
$$

で表される.
3.3 動特性係数の算出方法 静的平衡状態にあ るロータに, 微小変位 $\Delta X, \Delta Y$, 微小運動速度 $\Delta \dot{X}$, $\Delta \dot{Y}$, 微小加速度 $\Delta \ddot{X}, \Delta \ddot{Y}$ を与えたときに生じる液膜 反力の $X, Y$ 方向成分 $f_{X}, f_{Y}$ は, 12 個の動特性係数 $K_{i j}$, $C_{i j}, M_{i j}(i, j=X, Y)$ を用いて次式のように表すことが できる.

$$
\left\{\begin{aligned}
f_{X}= & f_{X 0}+K_{X X} \Delta X+K_{X Y} \Delta Y+C_{X X} \Delta \dot{X}+C_{X Y} \Delta \dot{Y} \\
& +M_{X X} \Delta \ddot{X}+M_{X Y} \Delta \ddot{Y} \\
f_{Y}= & f_{Y 0}+K_{Y X} \Delta X+K_{Y Y} \Delta Y+C_{Y X} \Delta \dot{X}+C_{Y Y} \Delta \dot{Y} \\
& +M_{Y X} \Delta \ddot{X}+M_{Y Y} \Delta \ddot{Y}
\end{aligned}\right.
$$

各動特性係数を求めるために $p$ を次式のように表す.

$$
\begin{aligned}
p & =p_{0}+p_{X} \Delta X+p_{Y} \Delta Y+p_{\dot{X}} \Delta \dot{X}+p_{\dot{Y}} \Delta \dot{Y} \\
& +p_{\ddot{X}} \Delta \ddot{X}+p_{\ddot{Y}} \Delta \ddot{Y}
\end{aligned}
$$

上式で例えば, $p_{X} \Delta X$ はロータの $X$ 方向に $\Delta X$ の微小 変位を与えたときの $p$ の変化量を表す. 同様にして, $\phi_{u}, \phi_{w}$ を次式で表す.

$$
\begin{aligned}
\phi_{u} & =\phi_{u 0}+\phi_{u X} \Delta X+\phi_{u Y} \Delta Y+\phi_{u \dot{X}} \Delta \dot{X} \\
& +\phi_{u \dot{Y}} \Delta \dot{Y}+\phi_{u \ddot{X}} \Delta \ddot{X}+\phi_{u \ddot{Y}} \Delta \ddot{Y} \\
\phi_{w} & =\phi_{w 0}+\phi_{w X} \Delta X+\phi_{w Y} \Delta Y+\phi_{w \dot{X}} \Delta \dot{X} \\
& +\phi_{w \dot{Y}} \Delta \dot{Y}+\phi_{w \ddot{X}} \Delta \ddot{X}+\phi_{w \ddot{Y}} \Delta \ddot{Y}
\end{aligned}
$$

また静的平衡状態にあるロータに $\Delta X, \Delta Y$ の微小変位 を与えたときのすきま $h$ は次式で表される.

$$
\begin{aligned}
h & =h_{0}+\Delta h \\
& =c+\left(X_{0}+\Delta X\right) \sin \theta^{\prime}+\left(Y_{0}+\Delta Y\right) \cos \theta^{\prime}+\gamma \cdot d_{p}
\end{aligned}
$$

ただし，ランド部で $\gamma 0$, 穴部で $\gamma 1$ である. また

$$
\begin{aligned}
h_{0} & \left.=c+\kappa_{0}(1+\cos \theta)\right) \\
& =c+X_{0} \sin \theta^{\prime}+Y_{0} \cos \theta^{\prime}+\gamma \cdot d_{p}
\end{aligned}
$$

であり， $\theta^{\prime}$ は鉛直上方からロータの自転方向に測った 角座標である（図 1 参照）。さらに式(20)より

$$
\dot{h}=\Delta \dot{h}=\Delta \dot{X} \sin \theta^{\prime}+\Delta \dot{Y} \cos \theta^{\prime}
$$

が得られる.

次に具体例として, $K_{X X}, K_{X X}$ を算出する場合の手順 を示す.

(1) 式(17)〜(19)において, すべての微小変動量を零と おく. 式(20), (22)より 


$$
h=h_{0}, \dot{h}=0
$$

となり，これらを基礎方程式に代入して， $p_{0} ， \phi_{10}$, $\phi_{w 0}$ を計算する. 得られた $p_{0}$ を式(11), (12)のpに 代入して $f_{\kappa 0}, f_{\theta 0}$ を求め, さらに式(13)-(15)を用い $\tau, f_{X 0}, f_{Y O}, X_{0}, Y_{0}$ を求める.

(2) 式(17) （19)において, $\Delta X$ 以外の微小変動量を零 とおく. 式(20), (22)より

$$
h=h_{0}+\Delta X \sin \theta^{\prime}, \dot{h}=0
$$

となり，これらを基礎方程式に代入して,

$$
\left\{\begin{array}{l}
p\left(=p_{0}+p_{X} \Delta X\right) \\
\phi_{u}\left(=\phi_{u 0}+\phi_{u X} \Delta X\right) \\
\phi_{w}\left(=\phi_{w 0}+\phi_{w X} \Delta X\right)
\end{array}\right.
$$

を計算する.

(3) $\Delta X$ を与えたときの液膜反力 $f_{X}, f_{Y}$ を次式により算 出する.

$$
\left\{\begin{array}{l}
f_{X}=-\int_{0}^{L} \int_{0}^{2 \pi}\left(p_{0}+p_{X} \Delta X\right) R \sin \theta^{\prime} d \theta^{\prime} d z \\
f_{Y}=-\int_{0}^{L} \int_{0}^{2 \pi}\left(p_{0}+p_{X} \Delta X\right) R \cos \theta^{\prime} d \theta^{\prime} d z
\end{array}\right.
$$

(4) 式(16)から導出される式

$$
\left\{\begin{array}{l}
K_{X X}=\left(f_{X}-f_{X 0}\right) / \Delta X \\
K_{Y X}=\left(f_{Y}-f_{Y 0}\right) / \Delta X
\end{array}\right.
$$

$$
\text { を用いて， } K_{X X}, K_{X X} \text { を算出する. }
$$

以下同様な手順で, 他の 10 個の動特性係数も求めら れる. な捦特性係数を算出する際に与える微小変動量は， その大きさが動特性係数に影響を及ぼさない範用の值を採 用することとし，本解析では平行環状シールの動特性解析 (12)に用いた值と同様，次式で与えた。

$$
\left\{\begin{array}{l}
|\Delta X|=|\Delta Y|=5 \times 10^{-3} \times c \\
|\Delta \dot{X}|=|\Delta \dot{Y}|=5 \times 10^{-3} \times c \omega \\
|\Delta \ddot{X}|=|\Delta \ddot{Y}|=5 \times 10^{-3} \times c \omega^{2}
\end{array}\right.
$$

\section{3·4 同心ふれまわり時の動的流体力と動特性係数} 本研究では数値解析結果の妥当性を調べるために実験 結果と比較する. 実験ではロータがシール内部を微小 同心ふれまわり運動している. したがって，実験で得 られた動的流体力及ひ動特性係数を, 3.3 節で算出され た動特性係数を用いて表す必要があり，以下に詳細を 述べる. なお，実験装置，実験方法については文献(8)
を参照してほしい.

図 2 に示すように，ロータは角速度 $\omega$ で自転しなが らシール中心 $\mathrm{O}_{\mathrm{S}}$ のまわりを半径 $e_{\mathrm{r}}$ 角速度 $\Omega$ ぶれま わっている. そのとき生じる動的流体力の半径方向及 びそれに直角方向成分をそれぞれ $F_{r}, F_{t}$ とする．同心 状態 $\left(\kappa_{0}=0\right)$ における動特性係数は次のように表され る.

$$
\left\{\begin{array}{l}
M_{m}=M_{X X}=M_{Y Y}, M_{c}=-M_{X Y}=M_{Y X} \cong 0 \\
C_{m}=C_{X X}=C_{Y Y}, C_{c}=-C_{X Y}=C_{Y X} \\
K_{m}=K_{X X}=K_{Y Y}, K_{c}=-K_{X Y}=K_{Y X}
\end{array}\right.
$$

式(26)を式(16)に代入すると， $\Delta f_{X}\left(=f_{X}-f_{X 0}\right)$, $\Delta f_{Y}\left(=f_{Y}-f_{Y 0}\right)$ は次式で与えられる.

$$
\begin{aligned}
{\left[\begin{array}{c}
\Delta f_{X} \\
\Delta f_{Y}
\end{array}\right] } & =\left[\begin{array}{cc}
M_{m} & 0 \\
0 & M_{m}
\end{array}\right]\left[\begin{array}{c}
\Delta \ddot{X} \\
\Delta \ddot{Y}
\end{array}\right]+\left[\begin{array}{cc}
C_{m} & -C_{c} \\
C_{c} & C_{m}
\end{array}\right]\left[\begin{array}{c}
\Delta \dot{X} \\
\Delta \dot{Y}
\end{array}\right] \\
& +\left[\begin{array}{cc}
K_{m} & -K_{c} \\
K_{c} & K_{m}
\end{array}\right]\left[\begin{array}{l}
\Delta X \\
\Delta Y
\end{array}\right]
\end{aligned}
$$

図 2 より式(27)中の各微小変動量は次式で表される.

$$
\left\{\begin{array}{l}
\Delta X=e_{r} \cdot \cos \Omega t, \Delta Y=-e_{r} \cdot \sin \Omega t \\
\Delta \dot{X}=-e_{r} \Omega \cdot \sin \Omega t, \Delta \dot{Y}=-e_{r} \Omega \cdot \cos \Omega t \\
\Delta \ddot{X}=-e_{r} \Omega^{2} \cdot \cos \Omega t, \Delta \ddot{Y}=e_{r} \Omega^{2} \cdot \sin \Omega t
\end{array}\right.
$$

式(28)を式(27)に代入し，さらに次の関係式

$$
\left\{\begin{array}{l}
F_{r}=-\Delta f_{X} \cdot \cos \Omega t+\Delta f_{Y} \cdot \sin \Omega t \\
F_{t}=\Delta f_{X} \cdot \sin \Omega t+\Delta f_{Y} \cdot \cos \Omega t
\end{array}\right.
$$

を用いると, $F_{r}, F_{t}$ は式(26)の動特性係数を用いて次式 のように与えられる.

$$
\left\{\begin{array}{l}
-F_{r} / e_{r}=-M_{m} \Omega^{2}+C_{c} \Omega+K_{m} \\
-F_{t} / e_{r}=C_{m} \Omega-K_{c}
\end{array}\right.
$$

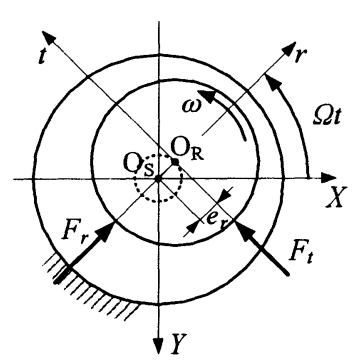

Fig. 2 Small whirling motion of rotor about seal center and dynamic reaction forces 


\section{4. 数值解析結果と考察}

解析の対象は四角穴シール, 及び比較対照となる平 行溝付シール，平行環状シールの 3 種類である. シー ル直径，シール長さはいずれも $D=71.725 \mathrm{~mm} ， L=60.0$ $\mathrm{mm}$ ，平均半径寸きまは $c=0.292 \mathrm{~mm}(2 \mathrm{c} / D=8 / 1000)$ で ある. 図 3 に四角穴シールのしゅう動面形状を示す。 穴は円周方向に 27 個, 軸方向に 7 個それぞれ等間隔に 配置されている。穴部寸法は $d_{\mathrm{x}} \times d_{\mathrm{z}} \times d_{\mathrm{p}}$ $=4.17 \mathrm{~mm} \times 4.0 \mathrm{~mm} \times 0.5 \mathrm{~mm}$, ランンド部は $l_{x} \times l_{z}$ $=4.17 \mathrm{~mm} \times 4.0 \mathrm{~mm}$ である. 平行溝付シールでは, 溝の 幅 $d_{\mathrm{z}}$, 深さ $d_{\mathrm{p}}$, 及び軸方向の配置は四角穴のそれらと 同じである. 作動流体 (水) の密度及び粘度 (水温 $26^{\circ} \mathrm{C}$

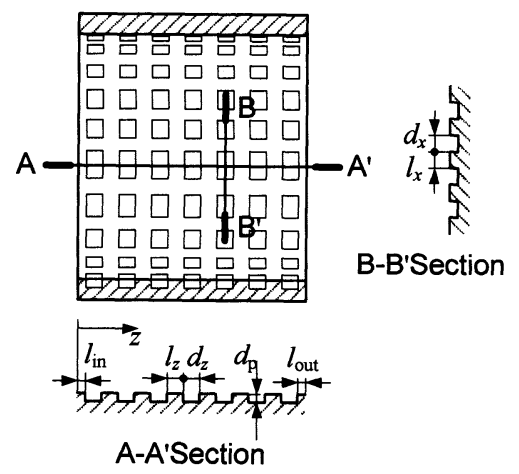

Fig. 3 Geometry of seal with square-hole pattern stator (cross-sectional view)

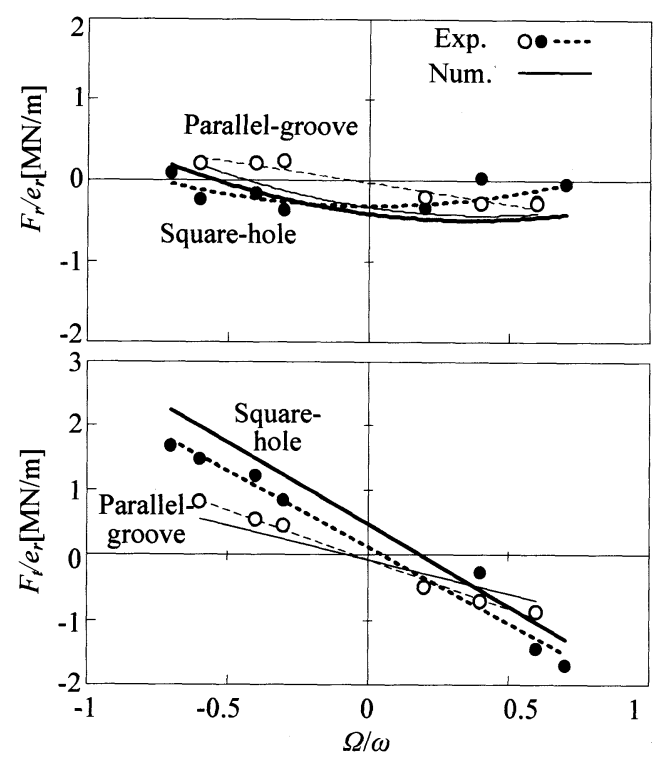

Fig. 4 Dynamic force coefficients versus ratio of whirling velocity to spinning velocity; $N=3000 \mathrm{rpm}, p_{\mathrm{d}}=686 \mathrm{kPa}$ ( $\alpha=0.25$ for square-hole pattern seal, $\alpha=0$ for parallel-grooved seal)
における）は $\rho=996.8 \mathrm{~kg} / \mathrm{m}^{3}, \mu=0.871 \mathrm{mPa} \cdot \mathrm{s}$ である.

4.1 動的流体力 図 4 亿動的流体力倸数 $F_{r} / e_{\mathrm{r}}$, $F_{t} / e_{\mathrm{r}}$ とふれまわり速度比 $\Omega / \omega$ との関係の代表例を示 す. 図中の実線は計算值，プロットしてある点は実験 值である. 破線は実験值を式(30)に基づき最小二乗法 を用いて， $F_{r} / e_{\mathrm{r}} ， F / e_{\mathrm{r}}$ をそれぞれ $2 \omega の$ 二次関数，一次 関数で近似している. 四角穴シール, 平行溝付シール ともに実験結果とおおむ㱛一致している．またF/e 大きさは四角穴シールのほうが平行溝付シールより大きい，

図 5 には, 図 4 とほぼ同じ条件下での, ロータの単 位幅あたりに作用する動的流体力成分 $\overline{F_{r}}, \overline{F_{t}}$ の軸方 向分布を示す． $\bar{F}_{r}$ はシール流入端で負值をとり，下 流に行くにしたがって増加し正值をとる. シール流入 端では圧力降下が周方向に不均一なことから静圧軸受 的効果が生じ，その結果シール流入端近傍で $\bar{F}_{r}$ が負 值になっている. ただし, 四角穴シールと平行溝付シ 一ルとの定量的な差は， $\bar{F}_{t}$ の場合にくらべて小さい.

一方, $\bar{F}_{t}$ はいずれのシールも正值で, シールの上流 側で大きくなっている． $F_{t}$ は周方向流れに対する流動 抵抗から生じるものであり，平均的なすきまが小さく せん断抵抗が大きい平行環状シールや，周方向流れが 穴部を通過する際の流動抵抗やエネルギ一損失を伴う 四角穴シールが，周方向に流動しや寸い円周溝を有す る平行溝付シールよりも $\bar{F}_{t}$ が定量的に大きくなって いる.

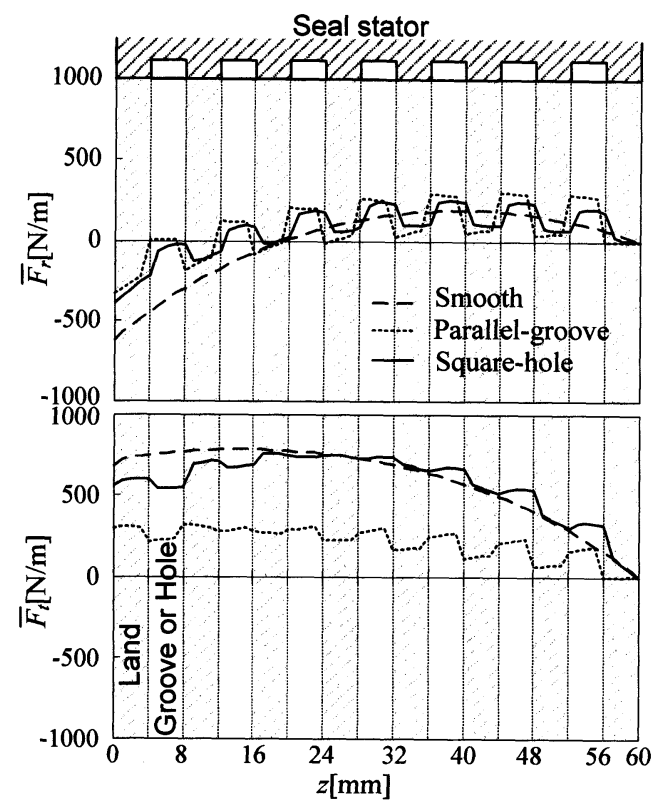

Fig. 5 Axial distributions of dynamic force components per unit seal length (Numerical results); $N=3000 \mathrm{rpm}, p_{\mathrm{d}}=686$ $\mathrm{kPa}, \Omega / \omega=-0.7(\alpha=0.5)$ 
$4 \cdot 2$ 動特性係数 図6に動特性係数とロー夕自転 速度 $N$ の関係を示す，実線及ひ破線は計算値，プロッ トしてある点は実験值である. 図より，減品釈数は実験 とよく一致している.ばね係数は実験との定量的な一致は 不十分であるが, $K_{\mathrm{mb}} K_{\mathrm{c}}$ ともに四角穴シールのほうが平行溝 付シールより大きい点で実験と定性的に一致している. 方, 付加質量俰数 $M_{\mathrm{m}}$ は実験值のばらつきが大きく, 計算 との比較は困難である. これは $M_{\mathrm{m}}$ の実験值が $F, e_{\mathrm{r}} \Omega$ 曲線 の曲率力ら決定されており, 他の動特性倸数に比へて $F_{r}$ 值 のばらつきの影響を受けやすいためである. したがってデ 一夕点数をさらに増やすなど測定精度の向上をはかる ことが今後の課題である.

動特性係数の中で四角穴シールの $C_{\mathrm{m}}$ は, 平行溝付 シールの 2 倍程度大きい.これは $F_{t}$ の場合と同じく, 周方向流れに対する流動抵抗の大きさの違いから生じ たものと考えられる.

以上, 図 4,6 より数值解析結果は実駼結果とおおむねー 致しており, 本解析の妥当性が検証された.

4.3 入口旋回流速度の影響 図7に入口旋回流速 度係数 $\alpha\left(=u_{\mathrm{i}} /(R \omega), u_{\mathrm{n}}\right.$ : 入口旋回流速度）と動特性係
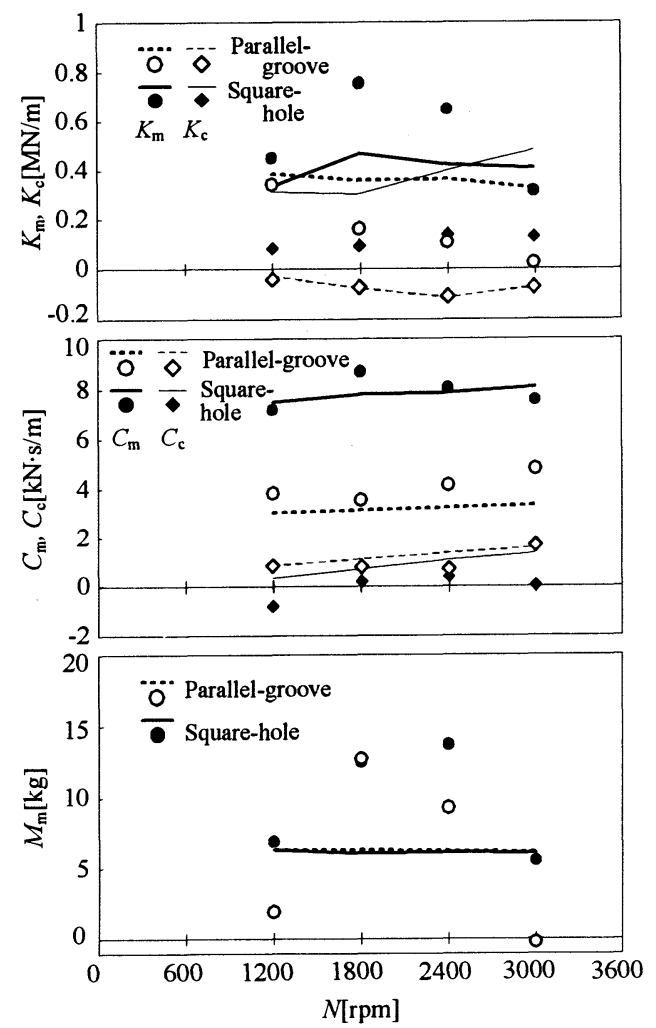

Fig. 6 Dynamic coefficients versus rotor spinning velocity; $p_{\mathrm{d}}=686 \mathrm{kPa}(\alpha=0.25$ for square-hole pattem seal, $\alpha=0$ for parallel-grooved seal)

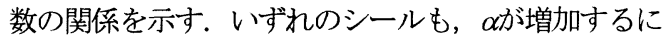
つれて, $K_{\mathrm{c}}, C_{\mathrm{c}}$ は増加し， $K_{\mathrm{m}}$ は減少する. これら係数 の $\alpha$ に対する変化率は四角穴シール, 平行溝付シール のほうが平行環状シールより小さい.一一方, $C_{\mathrm{m}}, M_{\mathrm{m}}$

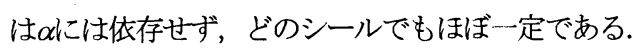

図 8 に $\alpha$ ふれまわり周波数比 WFR の関係を示寸. ロータが同心ふれまわり運動している場合（ $\left.k_{0}=0\right)$ は

$$
W F R=K_{\mathrm{c}} /\left(C_{\mathrm{m}} \omega\right)
$$

で与えられる(12). この值は式(30)で, $F_{t} / e_{\mathrm{r}}=0$ となる $\Omega \omega$ 值であり, 図 4 より, $0<\Omega / \omega<W F R(W F R>0$ の場合）または $W F R<\Omega / \omega<0 （ W F R<0$ の場合）で $F_{t}$ とふれまわり方向が一致してロータが不安定になる. したがってWFR の絶対值が小さいほどふれまわり運 動を抑制する $\Omega / \omega$ の領域が広がり, ロータの安定性 が増すことになる.

図より,いずれのシールも $\alpha$ ともにWFRは増加し, ロータのふれまわり運動に対する $\Omega / \omega$ の不安定領域 が広がる. 3 種類のシールで比較すると, 四角穴シー ルのWFRは $\alpha$ に対する変化が最も小さく, $\alpha>0.75$ で

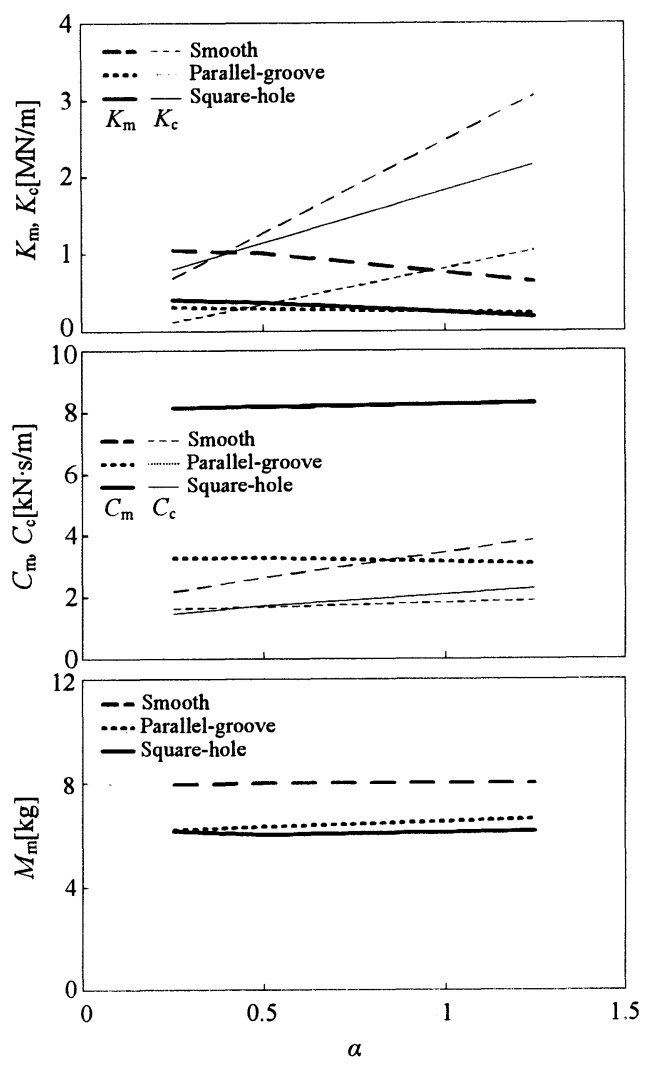

Fig.7 Dynamic coefficients versus seal inlet swirl velocity (Numerical results); $N=3000 \mathrm{rpm}, p_{\mathrm{d}}=686 \mathrm{kPa}$ 


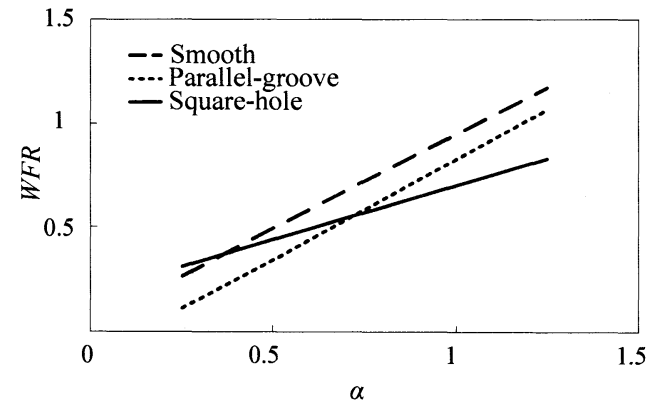

Fig.8 Whirl-frequency ratio versus seal inlet swirl velocity (Numerical results); $N=3000 \mathrm{rpm}, p_{\mathrm{d}}=686 \mathrm{kPa}$

は WFR の值も他の 2 つのシールより小さくなってい る. $\alpha$ 影響が小さくなるのは，しゅう動面に設けた 四角穴が周方向流れに対して抵抗となり，入口旋回流 速度がシールすきまの下流側に伝ぱするのを妨げてい るためである. また WFR の大きさについては，穴の 寸法などのパラメータを変更することによりさらに小 さくできると考えられる.

\section{5. まとめ}

本研究ではしゅう動面に四角穴パターンを有する シールを対象として, その動特性を理論的に解析した. すきま段差部での圧力変化を考慮に入れて, 乱流係数 を適用したすきまの厚さ方向に平均化した Navier-Stokes 方程式と連続の式を基礎方程式として, それらを連立して解き，すきま内の動的な圧力分布， 流速分布を求めた. また得られた結果より，ロータが シール内部を微小同心ふれまわり運動するときに生じ る動的流体力, 動特性係数を算出した.

その結果，動的流体力及乙動特性係数は実験とおおむれね 一致しており, 本解析の妥当性が検証された. 四角穴シ ールは平行溝付シールに比べて，ロータのふれまわり 運動を抑制する動的流体力及び主対角減衰係数が大き い.さらに, 四角穴シールは平行環状シールに比べて, 入口旋回流速度が動特性係数及びふれまわり周波数比 WFR に与える影響が小さく，また WFR の值も小さく なり，ふれまわり運動を抑制する点でロータの安定性 が向上する．四角穴シールと他のシールとのこのよう な差異は，周方向流れが穴部を通過する際の流動抵抗 やエネルギー損失に起因するものと考えられる。

なお，本研究の一部は平成 17 年度〜平成 18 年度科 学研究費補助金 (基盤研究(C)(2)) の援助を受けて行わ れたものであることを付記して謝意を表する。

\section{文献}

(1) Childs, D. W. and Kim, C. H., Analysis and Testing for Rotordynamic Coefficients for Turbulent Annular Seals with Different, Directionally-Homogeneneous Surface-Roughness Treatment for Rotor and Stator Elements, Transaction of the ASME, Journal of Tribology, Vol. 107, No.3 (1985), pp. 307-317.

(2) Childs, D. W. and Kim, C. H., Test Results for Round-Hole-Pattern Damper Seals: Optimum Configurations and Dimensions for Maximum Net Damping, Transaction of the ASME, Journal of Tribology, Vol. 108, No.4 (1986), pp.605-611.

(3) Childs, D. W. and Garcia, F., Test Results for Sawtooth-Pattern Damper Seals: Leakage and Rotordynamic Coefficients, Transaction of the ASME, Journal of Tribology, Vol. 109, No.1 (1987), pp. 124-128.

(4) Childs, D. W., Elrod, D. and Hale, K., Annular Honeycomb Seals: Test Results for Leakage and Rotordynamic Coefficients: Comparisons to Labyrinth and Smooth Configurations, Transaction of the ASME, Journal of Tribology, Vol. 111, No.2 (1989), pp. 293-301.

(5) Childs, D. W., Nolan, S. A. and Kilgore, J. J., Additional Test Results for Round-Hole-Pattern Damper Seals: Leakage, Friction Factors, and Rotordynamic Force Coefficients, Transaction of the ASME, Journal of Tribology, Vol. 112, No.2 (1990), pp. 365-371.

(6) Iwatsubo, T. and Sheng, B., An Experimental Study on the Static and Dynamic Characteristics of Damper Seals, Transactions of the Japan Society of Mechanical Engineers, Series C, Vol. 56, No. 523 (1990), pp. 673-680.

(7) Childs, D. W. and Fayolle, P., Test Results for Liquid Damper Seals Using a Round-Hole-Roughness Pattern for the Stators, Transaction of the ASME, Journal of Tribology, Vol. 121, No.1 (1999), pp. 42-49.

(8) Kaneko, S., Ikeda, T., Saito, T. and Ito, S., Experimental Study on Static and Dynamic Characteristics of Liquid Annular Convergent-Tapered Damper Seals With Honeycomb Roughness Pattern, Transaction of the ASME, Journal of Tribology, Vol. 125, No.3 (2003), pp. 592-599.

(9) Arghir, M., Billy, F., Pineau, G., Frene, J. and Texier, A., Theoretical Analysis of Textured "Damper" Annular Seals, Transaction of the ASME, Journal of Tribology, Vol. 129, No.3 (2007), pp. 669-678.

(10) Hirs, G. G., A Bulk-Flow Theory for Turbulence in Lubricant Films, Transaction of the ASME, Journal of Lubrication Technology, Vol. 95, No.2 (1973), pp. 137-146.

(11) Kaneko, S., Saito, T., Koyanagi, T. and Ito, S., Effects of Inlet Swirl Velocity on Static Characteristics of Annular Plain Seals (Numerical Analysis Based on Averaged Navier-Stokes Equations With Turbulent Coefficients), Transactions of the Japan Society of Mechanical Engineers, Series C, Vol. 67, No. 656 (2001), pp. 1123-1130. 
(12) Kaneko, S., Saito, T., Koyanagi, T. and Ito, S., Effects of Inlet Swirl Velocity on Dynamic Characteristics of Annular Plain Seals (Numerical Analysis Based on Averaged Navier-Stokes Equations With Turbulent Coefficients), Transactions of the Japan Society of Mechanical Engineers, Series C, Vol. 67, No. 656 (2001), pp. 1131-1138.

(13) Kanki, H. and Kawakami, T., Experimental Study on the Dyanmic Characteristics of Pump Annular Seals, IMechE, paper, C297/84 (1984), pp.159-166.

(14) Hori, Y., Fukayama, H., Tanaka, M, Kato, T. and Kaneko, S., Turbulent Lubrication Theory for Annular Plain Seals, Journal of Japan Society of
Lubrication Engineers, Vol. 30, No. 6 (1985), pp. 430-437.

(15) Kaneko, S., Taura, H., Ueda, N. and Henmi, K., Static Characteristics of Liquid Annular Seals With Square-Hole Pattern, Transactions of the Japan Society of Mechanical Engineers, Series C, Vol. 74, No. 745 (2008), pp. 2171-2181.

(16) Constantinescu, V. N. and Galetuse, S., Pressure Drop Due to Inertia Forces in Step Bearings, Transaction of the ASME, Journal of Lubrication Technology, Vol. 98, No.1 (1976), pp. 167-174.

(17) Arakawa, T., Computaional Fluid Dynamics for Engineeing, University of Tokyo Press, (1994), pp.123-126. 